\title{
USING WEB GIS FOR MARKETING HISTORICAL DESTINATION CAIRO, EGYPT
}

\author{
Reda Alkot MOHAMED ${ }^{1}$, Zakaria Yehia ABD EL GAWAD ${ }^{2}$, Mihai VODA ${ }^{3}$
}

DOI: $10.21163 / G T \_2021.162 .16$

\begin{abstract}
:
The article is analyzing the use of WebGIS for tourism development in historic Cairo which is considered as an open-air museum, designing the touristic map and publishing it on the web as an interactive map. ArcGIS Server and WebGIS were used to create and promote a platform guide for tourists enabling them to find the touristic places and services in an easy and quickly manner. Therefore, by using the WebGIS, the digitization of the cultural heritage will create a large quantity of digital images and maps of the study area, leading to an easy and accurate identification, analysis and interpretation of geographical data and touristic places attributes. The research results will contribute to local authorities better planning and decision-making process, having good impacts on the touristic development of Egypt in general.
\end{abstract}

Key-words: WebGIS, Hhistoric Cairo, Interactive map, ArcGIS Server, Cultural heritage, Tourism.

\section{INTRODUCTION.}

The success of planning for development depends on the availability of accurate information about the existing resources. It is, therefore, essential to conceive the ways and means of organizing computerized information system. These systems have to be capable of handling huge amount of data and represent it in an easy manner (Kumar and Babu, 2016). However, the use of GIS techniques will lead to an easy and accurate identification, measurement, analysis and interpretation of geographical data, all of these helping in good forecasting and aiding the decision- making process in tourism development. According to Amazon Web Services, ArcGIS is used to gain an understanding of the geographical location data and to take better informed decisions (Amazon Web Services, 2012).

The Internet is making the information and knowledge more common to the public, facilitating the desire to share and collaborate the geographic data over the web of many organizations who decided to develop their businesses with GIS resources (Law, 2013).

\subsection{Web GIS definition and development}

Web-based GIS (referred to as Web GIS) is a form of GIS that is deployed using an Internet Web browser (Reed and Bodzin, 2016). Maps from GIS applications were restricted to users of the local area network (intranet), but by Sharing these maps with anyone in anywhere by using the web, it will become a webGIS. Therefore, Web GIS is a Geographic Information System for the Internet. By using GIS, data and maps are stored in an infrastructure and can be configured to meet the digital mapping and IT requirements. We can share these spatial data with the users by using the Internet (Web GIS), because Web GIS is a hypertext-based service, allowing the users to browse data and information on networks. Also, the use of Web GIS has been growing in recent years, which is shown by the increasing number of GIS workstations that are distributed across the World Wide Web. It allows the sharing of resources and geographical information online easily and quickly within all over the world. Any user regardless of location and environment can have access to the geospatial data and GIS capabilities using the Web, enabling sharing the app with large number of users easily and quickly (Evic, 2004).

\footnotetext{
${ }^{1}$ Cairo University, Faculty of Arts, Geography department, Giza, Egypt: redaelkot@cu.edu.eg

${ }^{2}$ Thebes Academy, Department of civil engineering, Cairo, Egypt: z.yehia@thebes.edu.eg

${ }^{3}$ Dimitrie Cantemir University, Targu Mures, Romania: mihaivoda@cantemir.ro.
} 
Web GIS offers some of the same functions as a desktop GIS, but does not require the full suite of (often expensive) specialized software or tools that need to be mastered before one may effectively use the software. The utilization of GIS PC-programs may be difficult to public users (Reed and Bodzin, 2016). Web GIS facilitates a non-technical user to access the geographical information due to the friendly interface web-pages and apps which won't require prior specific GIS knowledge. These user-friendly systems, need to be developed continuously and to be kept simple in order to transfer the technology from the scientific community to the ordinary people (Kumar and Babu, 2016).

GIS and a Web GIS development may be expensive, but open source (OS) software, is available to this sector. Therefore, using these technologies is ranging from a free-cost software license to the flexibility of adapting the program to meet actual needs without depending on closed software. ArcGIS Online includes creating web app, and 3D web scenes. So Web GIS represents a considerable cheaper alternative when compared with the cost of building a stand-alone desktop solution which needs separate installation for every user. Moreover, the map can be modified or updated with additional data layers according to the user needs, making Web GIS useful to e-government, ebusiness, and daily life. ESRI and Amazon Web Services are offering an approach to running GIS applications in the cloud, with an overview of the most relevant individual storage options for geospatial applications building. The individual storage options form the building blocks that can be used to create web-scale geospatial applications (Amazon Web Services, 2012).

\subsection{Web GIS and tourism}

Tourism is an international activity that needs global publicity, and the map is a good visual advertisement for the attractions in any location. Given the use of GIS to facilitate understanding the relationships, patterns and trends between geo-referenced data (Reed and Bodzen, 2016), the use of GIS in the tourism industry leads to many studies concerned with highlighting the spatial dimensions of tourist sites, as well as planning and marketing them. With the availability of such systems, tourism marketing has become more accurate and flexible (Ahmed, 2011). Since GIS can link the map and descriptive information of these tourist places, and through the GIS on the Internet we can publish these tourism ads globally in an attractive way, by presenting the maps and tourist information in an organized manner to facilitate tourists use. Installing a program to prepare travel plans determines the use of Web GIS, where you can include all the data from online sources. It is automatically collected by connected tourism information systems (Wessel et al, 2006).

The role of GIS in the development of tourism in Historic Cairo will be through designing a tourist map system that contains an interactive tourist map and publishing it on the web by ARC GIS Server (AGS) to be a guide for tourists to find tourist places and their services easily and quickly, which will have good effects on tourism development in Egypt in general. Products are also displayed on the shelf to be marketed and create interest and attract people towards them (Hashmi, 2006). Similarly, any country can present itself as a tourist using the web by digitizing its cultural heritage, which will produce large amounts of digital images, and the creation of web interfaces for the general public will help in the exploration of such images by classifying them across time periods, places, geographical regions, or schemes thematic classification designed by the owners (Yao et al. 2020; Ernawati et al. 2018; Ilies et al. 2017). Also, through network analysis in GIS, tourism GIS technologies can have a role in determining the shortest route to tourist places that will be time-saving and economical (Gumusay 2004; Gupta et al. 2018; Voda and Montes 2018).

\subsection{Development and benefit of using webGIS for tourism in Cairo.}

By searching on the internet, no result are found about using WebGIS for Cairo. The only thing that is found is just some webpages for general tourism text information about Cairo (Viator, 2021), but without any maps. And also we found some other sites of general maps, but without any attributes data (Mapping Properties, 2021). And another GIS technology (mobile GIS) has been created for just a part in touristic Cairo-El moez street (Orchtech, 2021). 
This study is aimed to show how we can create webGIS for historical Cairo. Our intention is to develop a webGIS for tourism marketing in Cairo, because one of the benefits and advantages of using it will be its accessibility at the level of tourist personnel. Easy access to a particular landmark - know the path and know the monuments near its location. Easy to search in specific historical location and easy to update the base map and historical layer. This webGIS application saves the tourist from using paper maps and facilitates the quick and easy access to the historical landmarks. Not all the historical sites of Egypt are including GIS maps, they present only pictures and descriptions of the historical signs. Some other historical sites of Egypt are not including the nearest historical signs or search options. Therefore, tourists can easily access more detailed information about tours of Cairo on the Internet. And by developing webGIS for tourism marketing of Cairo, tourists can locate attractions of interest and check for accessibility equipment and the possibility of access through private or public transportation, improving the planning options of their visits.

The role of GIS in the development of tourism in historic Cairo is to design the tourist map system, which contains an interactive tourist map and post it online by ArcGIS Server, as a guide for tourists to find tourist destinations in an easy and fast way. Building an online GIS for historic Cairo is a good tourist ad, because tourism needs to be advertised globally. This goal can be achieved online. Especially using the map and the GIS capabilities feature by linking tourist sites and metadata to design a geographic information system on the Internet once and for all. Also, historic Cairo represents a unique form of cultural tourism that is now more attractive due to the exquisite history of those ancient places. This paper is useful to the local communities to better regulate and manage tourism activities. Therefore, web-based GIS provides an effective environment for the tourism industry. This may be very efficient in promoting the less known historic Cairo, where tourists planning to visit a particular place can get all the details from the GIS on the Internet. Web GIS has a friendly interface for the presentation of thematic maps, with some basic functionality for various types of content. Web GIS applications are opening new possibilities for planning and management of tourism activities because they allow more contribution to greater socialization of information. It represents a useful tool for planning and analysis of geographical data or distribution of services for tourism managers.

\subsection{Previous studies}

Web GIS is used in many fields such as health, economics, management, tourism, and others. In the Zambian Ministry of Health, the Zambian Ministry of Health is seeking to create a web-based GIS architecture with an intuitive and simplified user interface to enable non-specialist users to operate the system without any additional training. Managing a tool for monitoring and evaluating health facilities and developing a portal for public interaction with their spatial information (Mushonga et al, 2017). Web GIS maps were used to investigate malaria disease patterns and prevalence in relation to the environment in the Congo and their relationship to environmental and demographic factors to increase public health literacy through dynamic mapping for timely decision making (Reed and Bodzin, 2016)

In a web-based GIS used for the Chesapeake Bay watershed, clicking on a point of data will display its results. As well as creating simple graphs for it. An efficient standard in this web-based GIS is given by the fact that you can narrow down the investigation of data by specific date and location. This can be useful for comparing a specific site in different years. Also, you can filter the data by filter expression (Chesapeake Bay Foundation 2013). An interactive map of the RichmondSan Pablo, CA, USA area is designed to help visualize air quality monitoring sites, air pollution sources, and health burden data, and is intended to support the Steering Committee as it develops a community plan for air monitoring. The map can be modified or updated with additional data layers (Google Maps Help, 2020). The interactive map is produced by Google Maps that allows viewing and editing of maps for sharing online (Google Maps, 2020).

Web GIS is an essential tool for economic development as it provides continuous monitoring of crops and field activities. These systems are able to handle huge amount of data to set up a web-based 
GIS monitoring system for sugarcane, to help non-technical users to access information and take appropriate measures to improve crop production (Kumar and Babu, 2016).

The use of web-based GIS in management is demonstrated in an interactive Melbourne map of cooling and greening covering the city's urban areas. The interactive map provides a visual capture of vegetation data at the local, suburban, and Mesh Block levels. The vegetation data set also includes a layer that compares the change in vegetation cover between 2014 and 2018. These data sets are organized into multiple levels. (Victoria State Government, 2020). Another example is the city of Mesa that has made an interactive GIS map available to the public, to find a subdivision of the site, search the state history and find details about the size and owner of the property (Leeds City Council, 2020). Snohomish County Planning and Development Services also provided an interactive map for clients, partners and stakeholders. It provides quick access to a huge amount of information about unincorporated Snohomish County and using map attributes, navigate through topics, such as zoning, future land use, and capital facilities. It also provides a variety of tools for exploring data layers, as well as tools for searching and querying, creating and editing features, and annotations (Snohomish County, 2020).

Web GIS can be applied in teaching and learning as an innovative approach to enhance students' understanding in any subject. It is not only easy to use but also freely available online in teaching and learning history with map. A Web GIS could become more comprehensive like EnviroAtlas, which provides data, research, and analysis on the relationships between nature, people, health, and the economy. It is designed for use by government, professionals, academics, and community users as well as members of the public interested in ecosystem services. It provides multiple tools and GIS toolboxes, including an interactive map, and provides ready access to more than 400 maps and multiple analysis tools (EPA, 2020).

In tourism, the use of GIS led to building a marketing information system for tourism for the Aqaba Governorate, which resulted in saving time and effort and reaching accurate results in a very short time (Ahmed, 2011). Hyderabad has become a hot spot for international tourists, because it has developed into a global destination for information technology, which has contributed to promoting the tourism sector globally in an innovative and better way, thus increasing the country's economy in foreign currency (Hashmi, 2006). And through the development of Web GIS for Hainan Tourism Geographic Information System, it realizes map browsing, zooming, moving, information querying and marking of travel map, attractions, travel routing on electronic map with internet, and arrangement of travel plans on an interactive interface (Shi and Zhang, 2013).

On some web pages of open-air museums, such as in Belgium, it helps to show how to plan the tourist route and parking either by bike, train, bus or by car (Bokrijk, 2020). With the free app (Your Routing), you can download and print the resulting map in the state of Routing (Routeyou, 2020). Another app is "Self-Guided Tour", an app developed by GPSmyCity. This application turns the mobile device into a personal tour guide (Gpsmycity, 2020). By developing a web based Tourism Information System (TIS) for Eastern Uttar Pradesh, it has been modeled on a GIS platform to make it interactive and also connected to the internet to increase the accessibility of reliable information. Such a system is very useful for knowing the current state of tourism and implementing future tourism development programs. (Tyagi, 2014). Web GIS has also been produced in the field of Croatian nature tourism and mountaineering, to facilitate access to reliable information on mountaineering, visitor planning and thus the development of mountaineering tourism (Špoljarić, 2019), and in the GIS Tourist Network of Langkawi Island, is to allow public participation as a supply of information, such as adding an object or editing the attribute data (Masron et al. 2014).

To understand the different approaches to building GIS applications on the web to make geographic science more global, and having a large number of users, the Open Source Geospatial Foundation (OSGeo) has listed many applications that can support advanced mapping and geographic visualization tools (IFIC, 2004), and apply download the web, many of these applications that promote global adoption of open geospatial technology (Osgeo, 2020). GeoServer application for example is a server software that allows users to view and edit geospatial data, and allows great flexibility in creating maps, exchanging data, and displaying geographic information for the world 
(Geoserver, 2020). OpenLayers, GeoServer's integrated mapping library, offers quick and easy map generation. For example, MapServer is a platform for publishing geographic data and interactive map applications on the Internet. (Mapserver, 2020). GeoMoose can perform queries without using a server-side scripting language (Geomoose, 2020). PyWPS was started as part of the "Connecting of GRASS GIS (PyWPS, 2020) project. Other useful applications are represented by Degree Program, Mapbender and OpenLayers (Osgeo, 2020). Another example is the relationship developed between Wikipedia, WebGIS and Open Data Monument (ODM) to study the heritage sites of Emilia-Romagna for a profitable and profitable situation where all partners benefit from working together: ODM and Wikipedia pages related to heritage sites in Emilia-Romagna get access to reliable geo-reference and high-quality cultural data from WebGIS; WebGIS in turn gets free high-quality / usable images from ODM as well as a global view through Wikipedia (Magrini, 2018).

\section{STUDY AREA}

Cairo (Historic Cairo), the capital of Egypt, is considered a spatial acronym for a group of historical periods as an open-air museum like the open-air museums in Europe (Euro-t-guide 2020). The historic center (about 32 square kilometers) houses no less than 600 classified monuments dating back to the 7th century. It involved many streets and ancient dwellings, and thus retains forms of human settlement dating back to the Middle Ages, and this site is described as a historical tapestry of which large areas are still intact. Historic Cairo according to the appointment of the Egyptian Supreme Council of Antiquities as the only official concerning documents Set Historic Cairo, divided into five regions, and our study area will be limited to Zone 2 and it is the buffer zone that includes the Fatimid nucleus along with the Citadel area and the area around the Ahmed Ibn Tulun Mosque (UNESCO 2012).

Present-day Cairo is a contiguous chain of several successive historical sites over time. Since the Islamic rule of it in the year 640 during the caliphate of Omar ibn al-Khattab, and the construction of the first Islamic city of Fustat. After that, Ahmad ibn Tulun (809-904) built the city of Qatay in the year 870 near the city of Fustat. After that, the al-Khashid dynasty (935-969), the Fatimid dynasty (969-1171), which founded fatty Cairo. The Ayyubid dynasty (1171-1250) (Mary 2012), the Mamluk period (1250-1517).

From the previous history of Cairo, an unparalleled number of tourist buildings have been found (see Fig. 1). The most prominent architectural heritage of medieval Cairo dates back to the Mamluk period, which was characterized by comprehensive architectural projects, where we can find many uses in the same building, such as mosques that can be used as a school at the same time. Because the Mamluk sultans and elites were supporting religious and scientific life by building Religious complexes whose functions include a mosque, a madrasa, a khanqa (for Sufis) and water distribution centers (spills) at the same time. Among the most famous examples of Mamluk antiquities in Cairo that show these comprehensive religious complexes are the huge Sultan Hassan Mosque, the Sultan al-Ghouri complex, and three monuments in the Bayen Kasserine area that includes the Sultan Mansour Qalawun complex, the Al-Nasir Muhammad School, and the Sultan Barkouk School. Therefore, WHC developed Historic Cairo as well as the quantity and quality of historical monuments on the World Heritage List as one of the first historical cities to be included in the World Heritage (UNESCO 1979).

\section{DATA AND METHODS}

The most important tourist buildings in Historic Cairo, were categorized into Mosque(Mosques), Madrass(Madras), Qutab (Koranik Schools), Palaces and Bimaristans (Hospitals). These data are collected from Egyptian Survey authority, (1948), the Map of Cairo Islamic monuments, sheet 1\&2, 1:5000, Egypt, with polygon data type and display of the google maps in the back ground, the map scale is 1:5000 in UTM projection. 


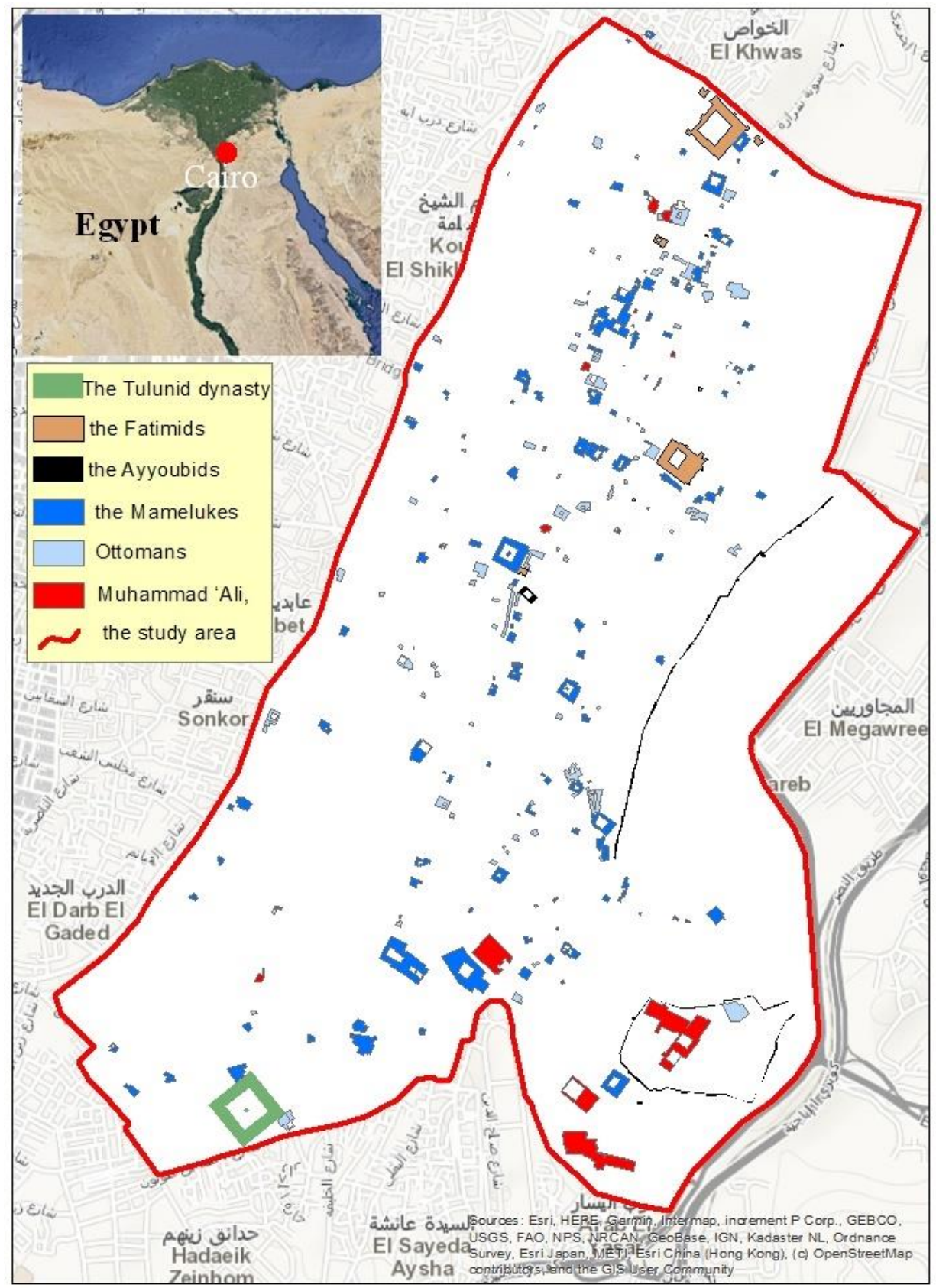

Fig. 1. Study area and density of historical monuments.

Deployed on the site by Arc GIS Web Manager Application, the site is created by selecting "Create Web Application Tool", then locate the data and add service layers using "Add Layer" (Add task) and through this tool add task Create procedural operations such as query attributes, search for attributes, and print and then they are modified to output the service (map). Adjust the map layout (such as map scale, north arrow).

Mosques: The first mosque in Egypt and Africa was the Amr Ibn Al-Aas Mosque in Fustat. While the Ibn Tulun Mosque represents the oldest mosque that retains its original shape and is a rare example of Abbasid architecture, from the classical period of Islamic civilization, so we can consider 
Historic Cairo to be influenced by the historical architecture of other civilizations such as the state The Abbasid as well as the Ottoman Empire, so it can be considered an open museum for the influences of a number of other civilizations. The Al-Azhar Mosque, which was founded in the Fatimid era, may compete with the Qarawis in Fez for the title of the oldest university in the world. Other monuments dating back to the Fatimid era include the Great Mosque of Al-Hakim Al-Ammar Mosque, and others.

Sabil-s: It is free drinking fountains for local communities, constructed by some sponsored by wealthy merchants and some by elites.

Madrasas (schools): Historic Cairo had many schools such as: Al-Azhar University, Baybars II Khanaqah, Al-Nasir Muhammad School, Al-Madrasah, the tomb of Al-Salih Najm Al-Din Ayyub, the Mosque-Madrasa of Sultan Barkouk

Caravanserais: (also known as wikalas or khanates) The Mamluks, and later Ottomans, built many souks and commercial buildings to house merchants and goods. The most famous example is the rich Wikala. Khan al-Khalili is a famous bazaar (Fahim, 1996), and a trading center. Another example of historical commercial architecture It is the Kasbah in the Gulf of Radwan in the seventeenth century, which is now part of the Khayamiya area whose name comes from the decorative textiles (Khayamiya) that are still sold there.

Fortifications (Walls, gates and Citadel): When the Fatimids established Cairo as a palace city in 969, parts of it remain today like walls and gates, for example: Bab Zuweila in the south, Bab alFutuh and Bab al-Nasr in the north. After that, the walls were extended and modified by the Ayyubids as part of Salah's plan Al-Din to protect both Cairo and Fustat with one set of walls and some Ayyubid gates such as Bab al-Barqiah. Salah al-Din also began building a vast castle in 1176 to be the headquarters of the authority in Egypt.

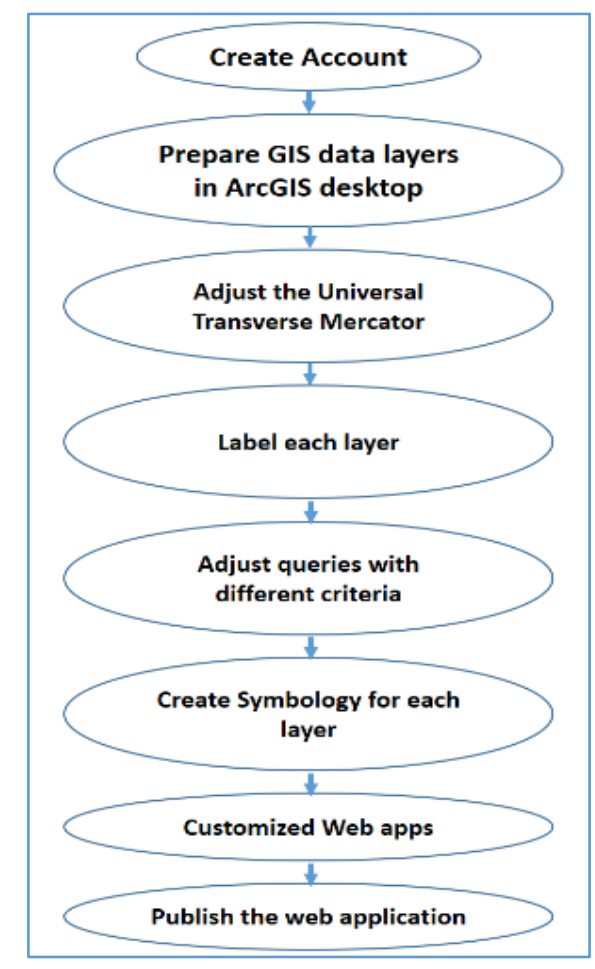

Fig. 2. Steps of creating WebGIS for Historic Cairo. 
Therefore, Historic Cairo is the densest in terms of its morphology and layers of history since the middle Ages. Cairo landmarks including public buildings, fortifications, and schools reflect intellectual prowess, and the numerous streets and squares reflect their commercial activities, many of which are seen as masterpieces in terms of the shape of its architecture. Thus, it celebrates the way in which the historic center of Cairo is a physical witness to the international importance of the political, strategic, intellectual and commercial activities of the city that developed during the medieval period as a lively, dynamic and multifunctional city. There were few cities in the world that were as rich at the time as Historic Cairo in terms of the way its ancient buildings display history. It was radically changed by recent developments or conflicts. Today`s Historic Cairo is an extraordinary survival, not only as a city Antique or as a museum but as a dynamic city that still easily displays its value (UNESCO, 2014).

The following chart (Fig. 2) shows the steps from creating an account in WebGIS till publishing the WebGIS application on the internet. Using ArcGIS to ease the use and prepare GIS maps and customize the WebGIS applications with symbology and different queries.

\section{RESULTS AND DISCUSSION}

The tourist map of any tourist site can be created through the program (Arc GIS Server) by adding geotourism data, so that this data is in the form of layers designed through the Arc Map program.

Creating the site is the beginning of specifying its primary administrator, as he has full powers to manage it, create users and define their tasks. Then specify the path to save server files and store services in the two folders (directory and configuration-store), and then the server starts uploading files to the two folders to activate the site. Finally create a web tourism application. (See Fig. 3).

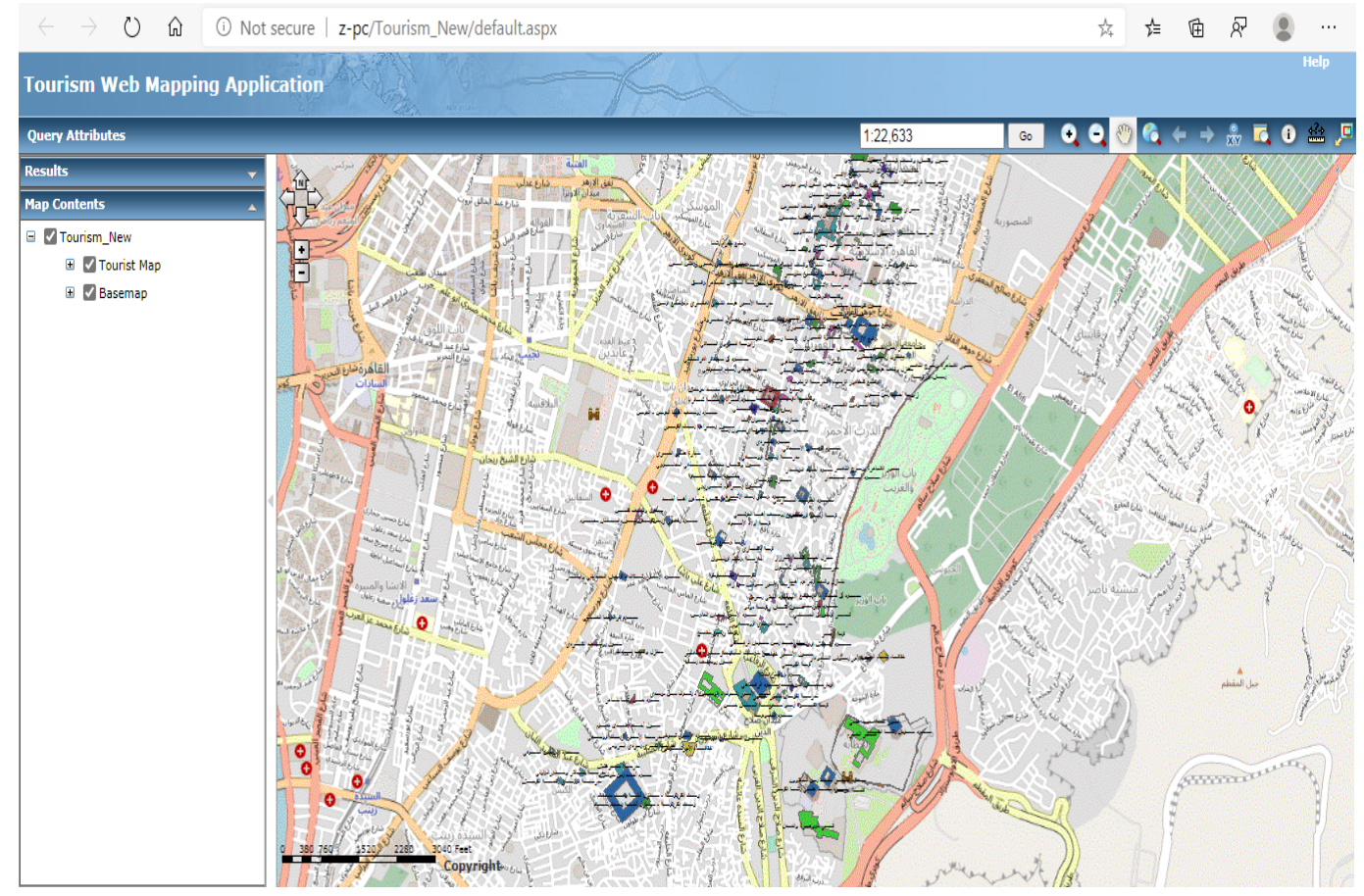

Fig. 3. Tourism web application (street map in the back ground). 
The tourist map and analytical operations are processed in the program (Arc Map). This is explained in the following steps:

- The interactive tourist map is prepared for the final output before it is published to ArcGIS

Server, so that it is suitable in terms of interactive (kinetic) and (technical) output.

- For the interactive map (full range), by choosing the appropriate scale for the appearance of the entire study area, and then the appearance of texts and symbols for the geographical layers.

To display the geographical tourism system, after the completion of the construction stages, the tourist map is displayed in all its layers, procedural and analytical processes as shown in Fig. 4. We can also make query about all kind of tourist buildings as shown in Fig. 5.

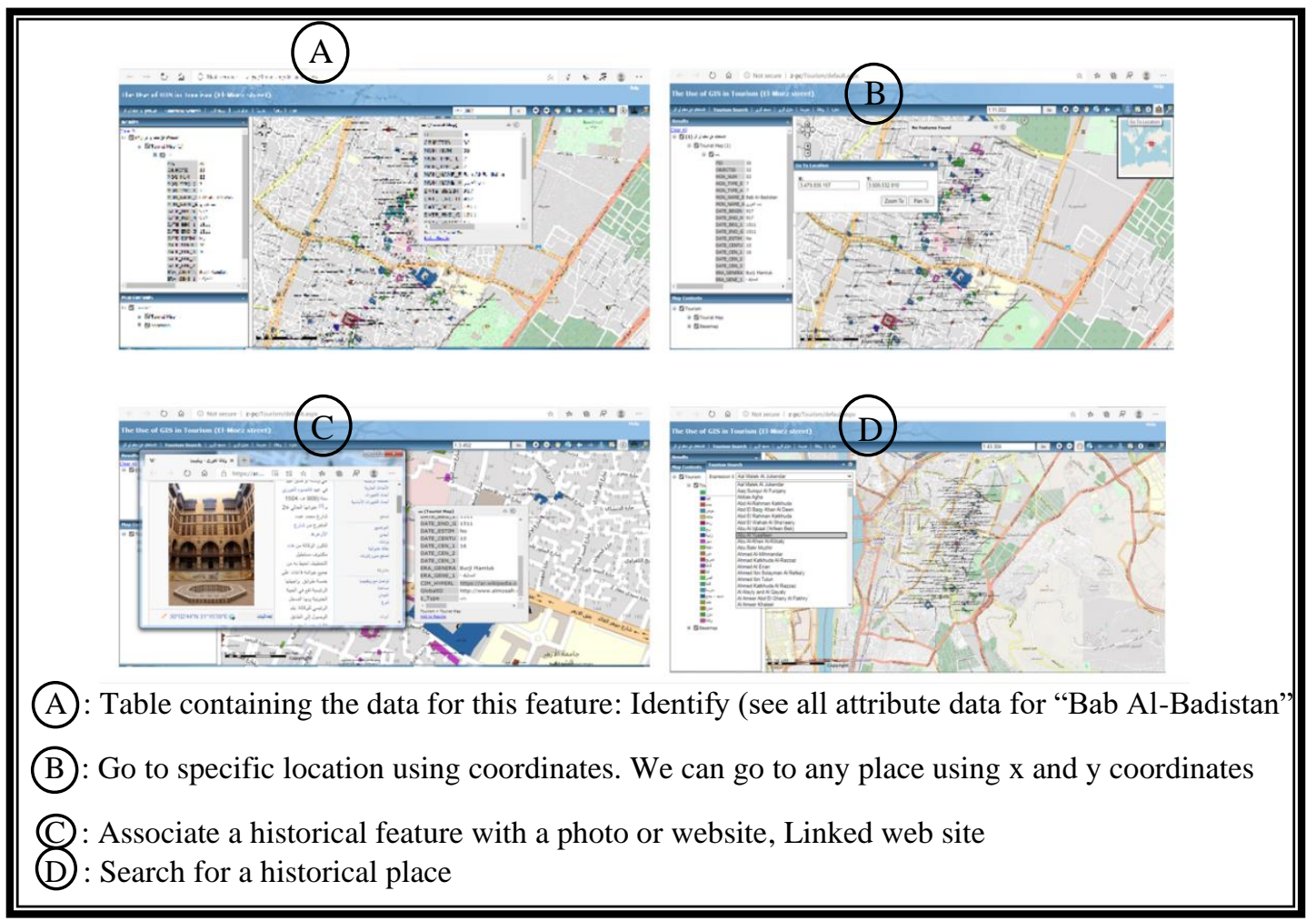

Fig. 4. Some advantages of using a GIS on the Internet for Historic Cairo.

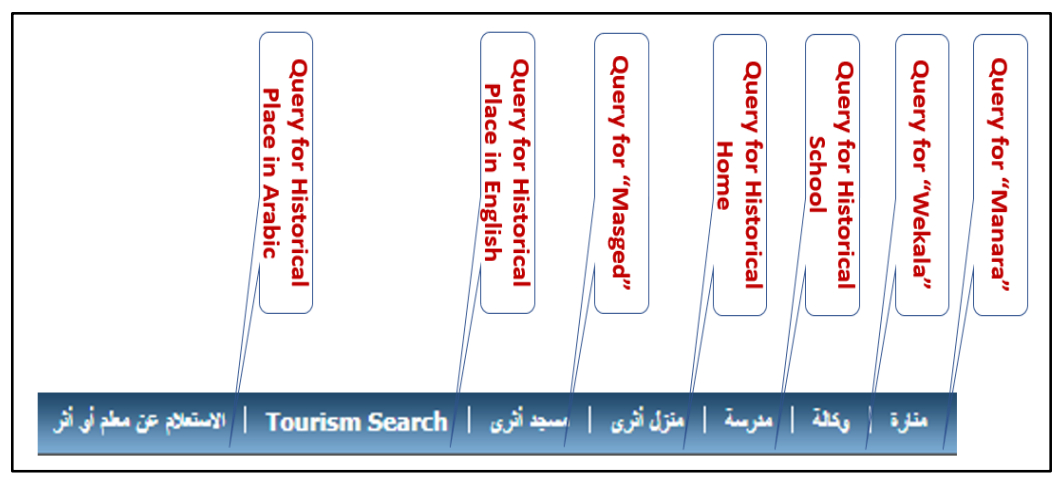

Fig. 5. Querying for each type of tourist building. 
The analysis finds that historical sites of Cairo are not including GIS maps, but only pictures and descriptions of historical signs. Some historical sites of Cairo do not mention the nearest signs and lack in search criteria, therefore, in our future work we aim to improve the WebGIS application by creating better Web/mobile apps to consume the same map and add Graphics and charts for supplementary data statistics in historical data.

\section{CONCLUSIONS}

Contemporary information technology greatly influences the development of tourism on a largescale, allowing visitors to always stay abreast of the latest tourist details. The role of our webGIS research in Cairo was to promote and stimulate tourism development by designing a tourist map system that contains interactive options and publishing it on the Internet by ARC GIS Server to be a guide that helps visitors to find attractive places in an easy and fast way. Building Web-GIS on the Internet for Historic Cairo represents a better promotion opportunity, because tourism needs to be more globally advertised. This goal can be achieved via the Internet especially using the map and the advantage of GIS capabilities by linking tourist sites and their metadata for the final web design. Historic Cairo might encapsulate a type of exquisite cultural tourism which is now becoming more and more attractive due to the history of the ancient places. This paper is useful for the local communities to better organize and manage their tourism activities. Therefore, a Web-based GIS provides an effective environment for the tourism industry. This article can be very helpful in promoting tourism in Historic Cairo, as tourists planning to visit a particular place can get all the details from the web-based GIS. Web-based GIS constitutes a spatial decision support system based on Geographical visualization approach using GIS technology and a virtual globe browser.

\section{R E F E R E N C E S}

Ahmed, A. (2011) Building a Marketing Information System for Tourism in Al Aqaba Using ARCGIS 9.3 Software. Master thesis-Business Management department. Middle East University.

Amazon Web Services. (2012) Mapping and Geospatial Analysis in Amazon Web Services Using ArcGIS. [Online]. Available from: https://media.amazonwebservices.com/AWS_ESRI_Mapping_GeoSpatial_Analysis_Using_ArcGIS.pdf. [Accessed June 2020].

Bokrijk. (2020) PLAN YOUR VISIT, Belgium. [Online]. Available from: https://www.bokrijk.be/nl/plan-jebezoek/route-parkeren. [Accessed June 2020].

Chesapeake Bay Foundation. (2013) Education - Water Quality Collection- Chesapeake Bay Foundation Water Quality Interactive Map. [Online]. Available from: https://cbforg.maps.arcgis.com/apps/webappviewer. [Accessed June 2020].

EPA. (2020) EnviroAtlas Interactive Map, U.S. [Online]. Available from: https://www.epa.gov/enviroatlas/about-enviroatlas. [Accessed August 2020].

Ernawati, N.M., Torpan, A. \& Voda, M. (2018) Geomedia role for mountain routes tourism development. Mesehe and Pisoiu Waterfall comparative study. Geographia Technica, 13 (1), 41-51.

Euro-t-guide. (2020) European Tourist Guide, Open-Air Museums, [Online]. Available from: http://www.eurot-guide.com/See_Type/Open_Air_1.htm. [Accessed August 2020].

Evic, S. (2004) The potential of Web-based GIS, Journal of Geographical Systems. 6(2):79-81.

Fahim. M. (1996) Urban classification of Cairo between theory and application, analytical study for Cairo- the City and the region. Master thesis in Engineering faculty, Cairo university.

Geomoose. (2020) Web Client JavaScript Framework, [Online]. Available from: https://www.geomoose.org. [Accessed June 2020]. 
Geoserver. (2020) What is Geoserver?, [Online]. Available from: http://geoserver.org/about. [Accessed July 2020].

Google Help. (2020) Create or open a map, Google. [Online]. Available from:

https://support.google.com/mymaps/answer/3024454?hl=en\&amp\%3Bref_topic=3188329. [Accessed June 2020].

Google Maps. (2020) Create or open a map, [Online]. Available from:

https://support.google.com/mymaps/answer/3024454?hl=en\&amp\%3Bref_topic=3188329. [Accessed August 2020].

Google Maps Help. (2020) Create a map in My Maps, Interactive Map for AB-617 Richmond/San Pablo [Online]. Available from:

https://www.google.com/maps/d/viewer?mid=1BQgFqbTLuuAECxpGebhiwzVpK9iIECzH\&ll=37.9246769 43579456\%2C-122.4013167072485\&z=10. [Accessed August 2020].

Gpsmycity. (2020) Cairo's Most Interesting Landmarks Tour (Self Guided), Cairo. [Online]. Available from: https://www.gpsmycity.com/tours/cairos-most-interesting-landmarks-tour-2479.html. [Accessed July 2020].

Gumusay, M. (2004) GIS Design and Application for Tourism. Yildiz Technical University Istanbul, Turkey.

Gupta, S.K., Negru, R. \& Voda, M. (2018) The Indian Himalaya`s unique attributes: Hemkund Sahib and The Valley of Flowers. Geographia Technica, 13 (2), 62-73.

Hashmi, M., (2006) "Explore Hyderabad” An Interactive Web-based GIS Application Prototype. Master's Thesis in Geoinformatics, Department of Computer and Information Science, Linköpings university, Sweden.

Ilies, A., Hurley, P.D., Ilies, D.C., \& Baias, S. (2017) Tourist animation -a chance adding value to traditional heritage: case studys in the Land of Maramures (Romania). Rev. de Etnografie şi Folclor, New Series 1-2.

Kumar, K., \& Babu, D. (2016) A Web GIS Based Decision Support System for Agriculture Crop Monitoring System, a case study from Part of Medak District. Journal of Remote Sensing \& GIS, 5 (4)

Law, D. (2013) ArcGIS for Server 10.1, Understanding architecture, deployment, and workflows, Special Section, [Online]. Available from: WWW.ESRI.com. [Accessed August 2020].

Leeds City Council. (2020) [Online]. Available from: https://southbankleeds.co.uk/map/poi-arts+poieducation+poi-services-structure+poi-leisure-retail+poi-commercial+poi-residential+landmarks-heritage. [Accessed June 2020].

Magrini, S. (2018) WebGIS, Cultural Heritage, Preservation, Tourism and the Wiki world: a case study from Emilia Romagna (Italy), JLIS.it, 9, 3.

Mapping Properties. (2021) Egypt Real estate Interactive Map, Cairo Interactive Map, [Online]. Available from: https://mapping.properties/cairo-map. [Accessed October 2021].

Mapserver. (2020) About MapServer [Online]. Available from: https://mapserver.org. [Accessed September 2020].

Marei, L, K. (2012) Revival of Mamluk Architecture in the 19th \& 20th centuries, A thesis in Islamic Art and Architecture, Department of Arab and Islamic Civilizations, School of Humanities and Social Sciences, the American university in Cairo.

Masron, T. Et al. (2014) Conceptualiste Tourism support system through Webgis for collaborative tourism planning, planning Malaysia: Journal of the Malaysian Institute of planners, V.XII.

Masron,T., Marzuki, A., Mohamed, B. \& Ayob, N. (2017) Development of a web based GIS for health facilities mapping, monitoring and reporting: A case study of the Zambian Ministry of health. South African Journal of Geomatics. 6(3).

Orchtech. (2021) El-moez, MOBILE APPLICATIONS [Online]. Available from: https://orchtech.com/casecategories/el-moez. [Accessed October 2021].

Osgeo. (2020) Open Source Geospatial Foundation (OSGeo), OSGeo Projects, Web Mapping. [Online]. Available from: https://www.osgeo.org[Accessed July 2020].

PyWPS. (2020) Web Processing Service, [Online]. Available from: https://pywps.org. [Accessed August 2020].

Reed, R. \& Bodzin, A. (2016) Using Web GIS for Public Health Education. international Journal of environmental \& science education, 11 (14).

Routeyou. (2020) Enjoy the nicest routes. [Online]. Available from: https://www.routeyou.com/user/planner/81970/limburg-fietsparadijs. [Accessed July 2020]. 
Shi, Y. \& Zhang, C. (2013) Tow-dimension display attribute marking of Hainan tourism geographic information based on the web GIS. Presented At: International Conference on Software Engineering and Computer Science (ICSECS).

Snohomish County. (2020) Planning and Development Services (PDS) Map Portal. [Online]. Available from: https://snohomishcountywa.gov/3752/PDS-Map-Portal. [Accessed July 2020].

Špoljarić, Z. (2019) Web GIS in mountaineering in Croatia, SPECIAL ISSUE - Applied GIS in the context of smart regions and cities. Original paper, GeoScape 13(2).

Tyagi, N. (2014) Web GIS application for customized tourist information system for Eastern U. P., India. Journal of Geomatics, 8 (1).

UNESCO. (1979) International council on monuments and sites (ICOMOS), world heritage list, (cultural Property) ICOMOS technical review Notes, The Secretariat World Heritage Committee, Division of Cultural Heritage, Paris.

UNESCO. (2012) Urban Regeneration Project for Historic Cairo, UNESCO World Heritage Centre Management of World Heritage Sites in Egypt, first report of activities, July 2010-June 2012

UNESCO. (2014) Report of a joint ICOMOS/UNESCO advisory mission to historic Cairo and the pyramid of Djoser, Saqqara, part of the world heritage property of Memphis and its necropolis - the pyramid fields from Giza to Dahshur, Egypt, p.8.

Viator. (2021) Cairo Tours. [Online]. Available from: https://www.viator.com/Cairo-tourism. [Accessed October 2021].

Victoria State Government. (2020) Cooling and Greening Melbourne Interactive Map, [Online]. Available from: http://mapshare.maps.vic.gov.au/coolinggreening. [Accessed July 2020].

Voda, M. \& Montes, Y.S. (2018) Descending mountain routes future: the North Yungas and Fagaras Geosystem`s comparative study. Geographia Technica, 13 (2), 152-166.

Wessel, H., Van, V., Hartleib, J. \& Dam, M. (2006) Web-Based GIS-usage in tourism, International Symposium on Geoinformatics for Spatial Infrastructure Development in Earth and Allied Sciences.

Yao, N., Chen, S., Wang, S. \& Yeh, C. (2020) Displaying spatial epistemologies on web GIS: using visual materials from the Chinese local gazetteers as an example, International Journal of Humanities and Arts Computing, 14, (1-2), Edinburgh University Press. 